【カテゴリーII】

\title{
㧖れを伴う 1 層構造物の最適強度分布と損傷分布 THE OPTIMUM STRENGTH DISTRIBUTION AND THE DAMAGE DISTRIBUTION IN ONE-STORY STRUCTURES INFLUENCED BY TORSION
}

\author{
島崎 大*, 秋山宏**
}

Dai SHIMAZAKI and Hiroshi AKIYAMA

\begin{abstract}
In this paper, elastic-plastic dynamic response analysis of one story vibrational models with eccentricity are carried out. From results of analyses, it was concluded that in eccentric structures having the optimum strength distribution which can be obtained by means of modal analysis no damage concentration occurs in specific structual planes. In structures having general ( not optimum) strength distribution, damage concentration can be estimated by applying the parameter $p_{t i}$ which indicates the defference between the actual strength distribution of the structure and its optimum strength distribution.
\end{abstract}

Keywords : torsional vibration, eccentricity, optimum strength distribution, damage distribution 据扎振動，偏心，最適強度分布，損傷分布

1 序

偏心を有する構造物は，地震時に建物全体が摸れることにより， 特定構面あるいは特定部材への損傷集中がおき，これが椿造物全体 の崩壇・大破の原因となる可能性がある。過去の地震被害の中に も，挨れによるものと思われる被害が報告されておりり，耐震設計 上の配慮が必要とされる。

このような状況から，㨝れを伴う構造物の酎震性能を，立体架構 の応答性状から検討しょうと試みた研究は数多い。秋山・東は 1981 年に施行された新耐震設計法における，偏心率 $R e$ による必要保有 水平酎力の割増率 $\mathrm{Fe}$ についての検討を行っている2)。また，尾崎 · 小豆畑らはせん断一ねじれ耐力比 $e R$ を提案し、これを指標とした 損傷予測を試みている3ほか，大網・村上は，1層1軸偏心系の弾 性解析をもとに，ねじれ成分の特性について考察している4。これ らの研究は無偏心構造物を基準として，据れによる損傷集中権面の 損傷の度合いのみに着目して層ごとの強度の割増率について検討し ているが，挨れを伴う構造物の総合的な耐震性能を評価する手法は 確立されてはいないのが現状である。

* 東京大学大学院 大学院生

** 東京大学工学部建筑学科 教授 $\cdot$ 工博
地震動をエネルギーとしてとらえた場合，構造物への地震による 入カエネルギー量は挨れの度合いに影響されないことが既に明らか にされている2。このことから，挨れ振動を把握するうえでは，据 れによる構面ごとの損傷分布の変化を支配するパラメータを明らか にすることが非常に重要であるといえよう。

上述のパラメータに関しては, 弾性時の偏心の度合・強度の不验 合いなどに着目して，既に様々なものが提案されているが，本研究 においては，据れを伴う弾塑性応答では弾性時の偏心と強度のバラ ンスとの関係が支配的であるという考え方に基づいて，せん断型の 多層平面骨組において既に提案されているような，各層の損傷を均 一化させる最適降伏せん断力保数分布のを，挨れを伴う立体架構に も設定しょうと試みた。強度の適正配分という点に関しては，同粎 の研究として, 佐武の研究のが挙げられるが, 扱うモデルが不整形 状を有する構造物に限定されており，一般的な据れ振動モデルによ る損侮分布については言及されていない。

本研究では，最適強度分布の設定の妥当性を確認するとともに， 偏心構造物の摸れ振動特性を評価するのに適切であること考えられ Graduate Student, Univ. of Tokyo Prof., Dept. of Architecture, Faculty of Engineering, Univ. of Tokyo, Dr. Eng. 


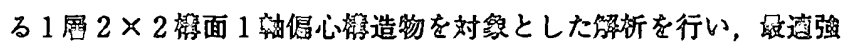
度分布を基準として，せん断型平面骨組と同橔の手法により，搌れ による損倾分布を評洒した。

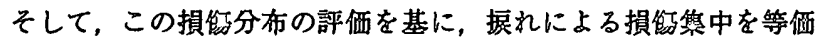

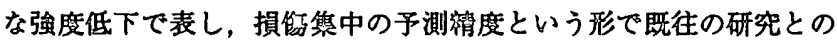
比辡を行うことで，その有効性を碓証する。

\section{2 程道傺应分市の設定}

段䝵强度分布の設定方法の概要は以下の通りである。 最適強度分布が入カレベル，強度レベルに依存しない形で設定で きるならば，入力レベルを下げるか強度レベルを上げると符造物の 損解はぜロになることから，取適強度分布は弾性振動系のせん断力 分布に一致する。

よって，聂道強度分布は，等価潓庋応答スペクトル（ $V_{E}$ スペク トル（図1参照)）を用いたモータル・アナリシスにより以下のよ うに求めることができる。ここで、 $V_{E}$ は入力エネルギの遂度撸筑

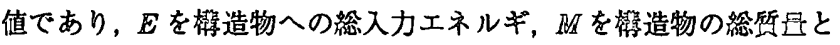
して,

$$
V_{E}=\sqrt{\frac{2 E}{M}}
$$

で表される。

1) 振動系への䉥エネルギ入力 $E$ は各次モードに対して入力される エネルギの和となる。

2) $i$ 次モードに対して入力されるエネルギ $E_{i}$ は $i$ 次の刺激係效 $\beta_{i}$ と $i$ 次固有周期とを用いて,

$$
E_{i}=\beta_{i}^{2} \frac{1}{2} M\left\{V_{E}\left(T_{i}\right)\right\}^{2}
$$

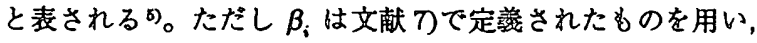
$\sum \beta_{i}^{2}=1$ となるよう規準化した。また， $V_{E}\left(T_{i}\right)$ は固有周期 $T_{i}$ に对 応する $V_{E}$ の值を示す。

3）各次モードへの入力エネルギ $E_{i}$ がすべて㭢面の変形によって 吸收されたと考えて，各構面のせん断力の最大値を求奴。

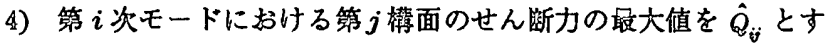

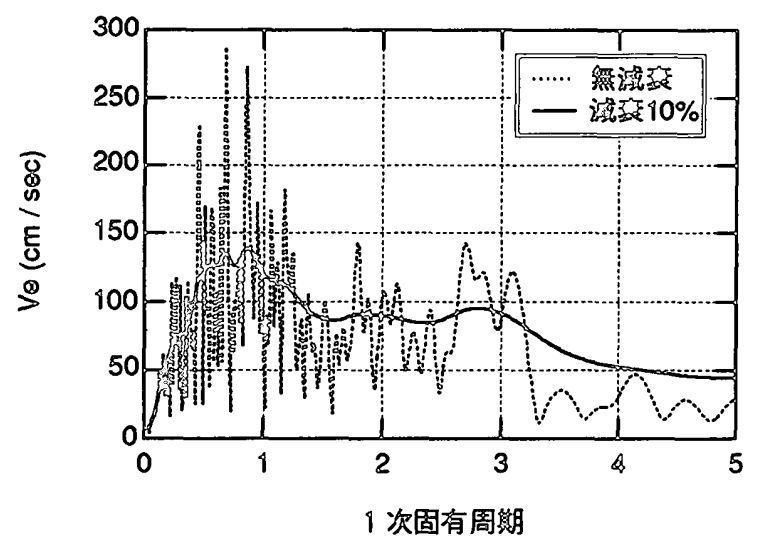

図 $1 V_{E}$ スペクトル
ると，第 $j$ 筇面の弾性時のせん断力の㖩大值は，以下のように近似 できる8 。

$$
\hat{Q}_{j}=\sqrt{\sum_{i} \hat{Q}_{i j}^{2}}
$$

5) 第 $j$ 㛵面の強度を $Q_{j}$ とすると, 取適強度分布は以下のように 与えられる。

$$
\frac{Q_{j}}{\sum Q_{j}}=\frac{\hat{Q}_{j}}{\sum \hat{Q}_{j}}
$$

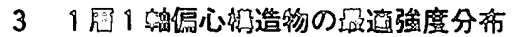

㯇造物は多榑面を有するのが一没的であるが，多梅面骨組を不用 意に扔うことは現象をいたずらに複雑にするた゚けであり，据れ振勘 特性を把握するには適さない。このため, 従来から层れ振勘特性を 評価するモデルとして，2×2 棈面モデルが多く用いられており， 一般の㩐造物をこのモテルに置換する方法も提案されている2か。

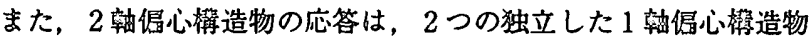
の応答の 2 乗平方和で大まかな推定が可能であるという指摘がある ことを考慮しッ，本報では搌れ振動による損能配分を大局的にとら えるという钼点から，完全弾望性型の履歷特性を持つ 1 绝 $2 \times 2$ 筑

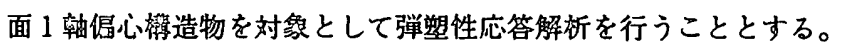

\section{4 解析モデル}

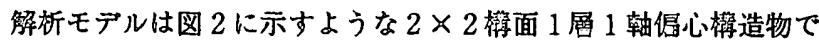
ある。床面は矩形であり，啠进偏心はないものとする。また，据れ を無視した並進時の弾性 1 次固有周期 $T$ は， $x, y$ 各方向とも，

$$
T\left(=2 \pi \sqrt{\frac{M}{K}}\right)=1.0 \mathrm{sec}
$$

とする。ここで芯は矮造物の総甽性を表す。

系の镕強度は， $x$ 方向の降伏せん断力係敨を $\alpha$ として，

$$
\alpha\left(=\frac{Q}{M g}\right)=0.2
$$

とした。なお，地動入力は $x$ 万向のみとし，直角方向である $y$ 方 向は稱性に留まるものと仮定する。

このとき，權造物の振動特性を決定するパラメ゙ー夕は，筑 $\mathrm{X} i$ 檍

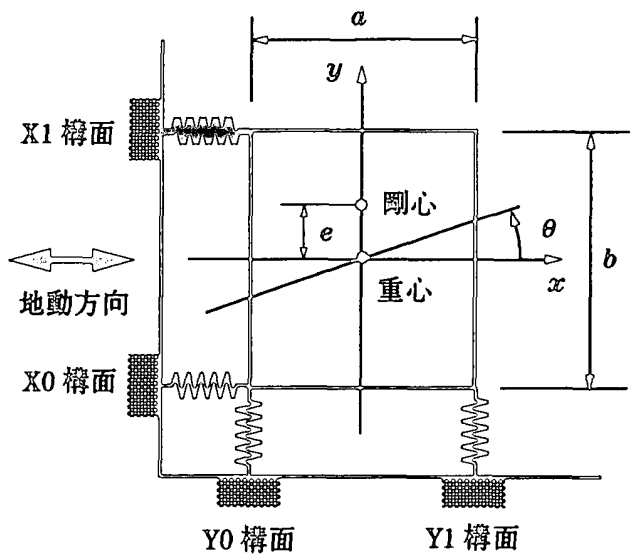

図 2 解析モデル 
面の剛性を $k_{\mathrm{i}}$, 強度を $q_{\mathrm{i}}$ として，
1) $x$ 方向の剛性分布 $k_{0} / K$
2) 辺長比 $b / a$
3） $x$ 方向の強度分布 $q_{0} / Q$

の3つとなる。なお, 強度・剛性については，

$$
K=\sum_{i} k_{i}, Q=\sum_{i} q_{i}
$$

なる関係式が成立する。

前述の 3 つのパラメータのうち，1)2)が決定すると，それに対し て前述の手法により，最適強度分布を求めることができる。そこ で，本報では，解析パラメータとして，1)および2)を採用し，そ れぞれを series A および series B と呼ぶことにする。各 series の諸 元は以下の通りである。

series A（解析パラメータ : $x$ 方向の㓮性分布）

床面形状は正方形（ $b / a=1 ） と し ，$ 剛性分布を，

$$
k_{0} / K=0.1,0.2,0.3,0.4,0.5
$$

の範囲で変化させた。これらをそれぞれ model A01, A02, A03, A04， A05 と呼ぶことにする。図 3 にモード解析の一例を示す。1次モー ドは $x$ 方向並進主体の摸れモード，2次モードは $y$ 方向並進モー ド，3次モードは 1 次モードと同様の据れモードであるが，回転成 分が支配的である。これらのモデルに対して，前述の最適強度分布 を求めた。表 1 に最適強度分布の一覧を示す。なおここで用いた

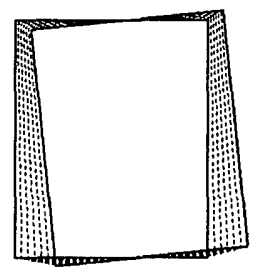

1 次モード $1.02 s e c$

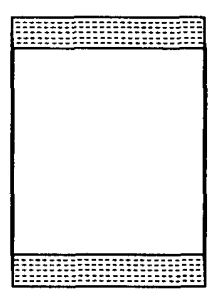

2 次モード $1.00 \mathrm{sec}$

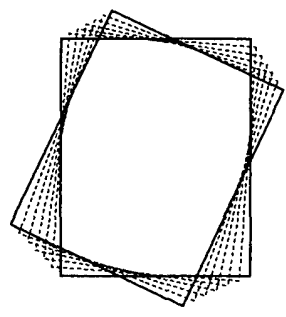

3 次モード

$0.57 \mathrm{sec}$
$V_{E}$ スペクトルは El Centro NS 成分の減衰 $10 \%$ に㧍けるものであ る。

series B（解析パラメータ：辺長比）

剛性分布を $k_{0} / K=0.4$ に固定し, 辺長比を， $b / a=1 / 5,1 / 2,2 / 3,1,3 / 2,2,5$

の䡉囲で変化させた。これらをそれぞれ model B01, B02, B03, B04， B05, B06, B07 と呼ふことにする。これらのモデルに対しても同粎 にして最適強度分布を求めた。これも，表1に示す。

\section{2 解析方法}

応答解析は 1 方向のみの入力で行った。入力地祳波は，El Centro NS 成分であり，加速度倍率を $0.5 \sim 2.25$ の間で複数設定し た。応答解析は線形加速度法により，時間刻みは 0.002 秒である。 なお，減衰は考慮していない。

\section{3 解析結果の評価方法}

各構面への損傷を㨭れを無視した 1 質点系の累積塑性変形倍率 $\eta_{n}$ に対する挨れ系の累積塑性変形倍率 $\eta$ の割增率 $\chi$ で評価する。 ここに,

$$
\chi=\frac{\eta}{\eta_{n}}
$$

である。また，完全弾塑性系においては，エネルギの釣合いから， 弾性振動エネルギを無視すると，挨れを無視した 1 質点系の累積塑 性変形倍率 $\eta_{n}$ は，以下のように表すことができる2)。

$$
\eta_{n}=\frac{A_{E}}{\alpha^{2}}
$$

ここで， $A_{E}$ は入力エネルギの無次元化量であり，入力エネルギを $E$ とすると, $A_{E}=E / \frac{M g^{2} T^{2}}{4 \pi^{2}}$ である。以下, $\mathrm{X} i$ 構面の累積塑性変 形倍率を $\eta_{i}$ ，その並進系に対する割増率を $\chi_{i}$ とする。

図 $4 k$, 各構面の累積塑性変形倍率 $\eta_{i}$ と $A_{E} / \alpha^{2}$ との関係の一 例を示す。これより，入カレベルが損傷分布に影響を与えないとい う最適強度分布設定の際の仮定の妥当性が確認できる。そこでこれ らの結果を最小 2 乗法により原点を通る直線で近似し，各モデルの

\begin{tabular}{|c|c|c|c|c|c|c|c|c|c|c|c|c|}
\hline model & $\mathrm{A} 01$ & $\mathrm{~A} 02$ & $\mathrm{~A} 03$ & $\mathrm{~A} 04$ & $\mathrm{~A} 05$ & B01 & $\mathrm{B} 02$ & B03 & B04 & B05 & B06 & B07 \\
\hline \multicolumn{13}{|l|}{ 辺長比 } \\
\hline$b / a$ & 1.0 & 1.0 & 1.0 & 1.0 & 1.0 & 0.2 & 0.5 & 0.67 & 1.0 & 1.5 & 2.0 & 5.0 \\
\hline \multicolumn{13}{|l|}{ 剛性分布 } \\
\hline$k_{0} / K$ & 0.1 & 0.2 & 0.3 & 0.4 & 0.5 & 0.4 & 0.4 & 0.4 & 0.4 & 0.4 & 0.4 & 0.4 \\
\hline$k_{1} / K$ & 0.9 & 0.8 & 0.7 & 0.6 & 0.5 & 0.6 & 0.6 & 0.6 & 0.6 & 0.6 & 0.6 & 0.6 \\
\hline \multicolumn{13}{|c|}{ 最適強度分布 } \\
\hline$q_{0} / Q$ & 0.215 & 0.342 & 0.422 & 0.471 & 0.500 & 0.405 & 0.428 & 0.444 & 0.471 & 0.498 & 0.514 & 0.536 \\
\hline$q_{1} / Q$ & 0.785 & 0.658 & 0.578 & 0.529 & 0.500 & 0.595 & 0.572 & 0.556 & 0.529 & 0.502 & 0.486 & 0.464 \\
\hline
\end{tabular}
各構面に対して，式(8)，(9)で得られる值を $\chi_{i}$ とした。

図 3 弾性モード形（model B05）

表 1 モデル諸元 


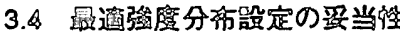

表 2，图 5 に取適強度分布下での各モデルの鼠致塑性变形倍率の

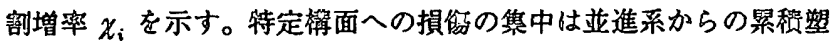

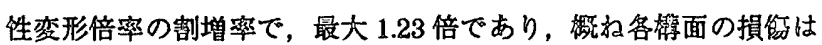
均一であるとみなせる。このことから，取適強度分布の設定が有効 であることが確認できる。

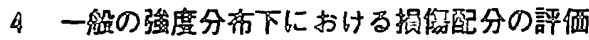

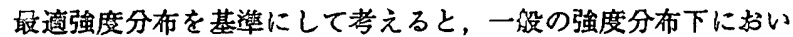

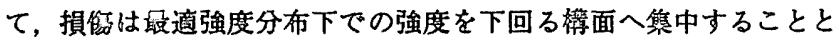
なる。

そこで，取適強度分布に従わない任意の強度分布を持つ棈造物の 損份配分について釦討するため，前还の series A，B 全てのモデル に対し，強度分布を，

$$
q_{0} / Q=0.1,0.2,0.3,0.4,0.5,0.6,0.7,0.8,0.9
$$

の䈖囲で変化させた計 108 モデルに関して，応答解析を行う。

ここで，第 $i$ 構面の降伏せん断力係数 $\alpha_{i}$ を，文献 2)と同㥞に，

$$
\alpha_{i}=\frac{2 q_{i}}{M g}
$$

とし，降伏せん断力係效分布を第 $i$ 棈面の降伏せん断力係效の層全 体の降代せん断力係效に対する比 $\alpha_{i} / \alpha$ で定艃する。

そして，系が最適強度分布に従う場合の降伏せん断力係数分布 $\alpha_{i} / \alpha$ を殹適降伏せん断力係数分布と呼び， $\bar{\alpha}_{i}$ と表すことにすれ
ば，梥際の強度分布の哽適強度分布からの「ずれ」の度合いを表す 指標として,

$$
p_{i s}=\frac{\alpha_{i} / \alpha}{\bar{\alpha}_{i}}
$$

がとれる。

图 6 にこの $p_{t i}$ と $\chi_{i}$ との関係を示す。図 6 (a) は甽性分布をパ ラターータとした場合であり，図6(b)は边長比をパラメータとした 場合である。いずれの場合も $p_{i \dot{b}}$ と $\chi_{i}$ との関係は同㥞の傾向を示 している。このことから，据れによる損筇焦中の度合いには，むっ ばら当該䧳造物の強度分布の最適強度分布からのずれの度合いが支 配的な影飨を与えるといえる。 $p_{t i}$ と $\chi_{i}$ とには概ね，

$$
x_{i}=p_{t i}^{-n}
$$

なる関係があることが認められよう。解析結果から, 式(12)の $n$ は概初 2〜 3 程度であることが分かる。

式(12)梳れによる損街俈中を評価したものであると考えられ

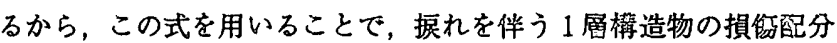
を以下のように導くことができる。

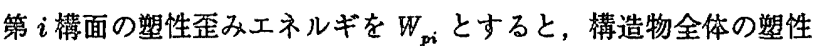
歪みエネルギを $W_{p}$ は以下のように与えられる。

$$
W_{p}=\sum W_{p i}
$$

また，第 $i$ 棈面の降伏変形を $\delta_{Y i}$ とすると，

$$
W_{p i}=q_{i} \delta_{k i} \eta_{i}
$$

が成立する。ここで， $k_{i}=\kappa_{i} K$ とすれば，式(5)より，

$$
\delta_{Y_{i}}=\frac{q_{i}}{k_{i}}=\frac{q_{i} T^{2}}{4 \pi^{2} M \kappa_{i}}
$$

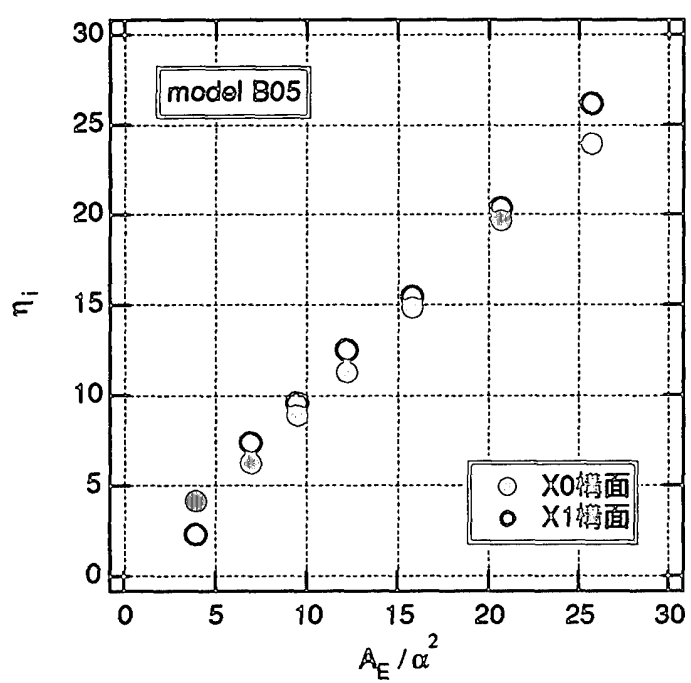

図 4 加速度倍率の变化による $\eta$ の变化の一例

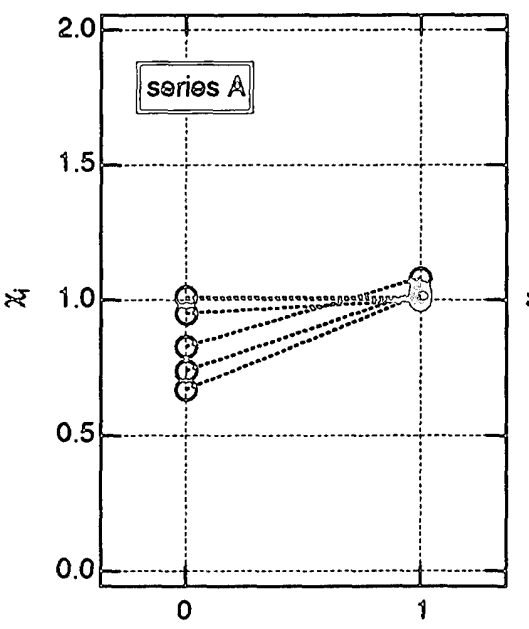

徨面瑟号（火方向）

図 5 最適強度分布下での累積塑性変形倍率の割增率 $\chi$

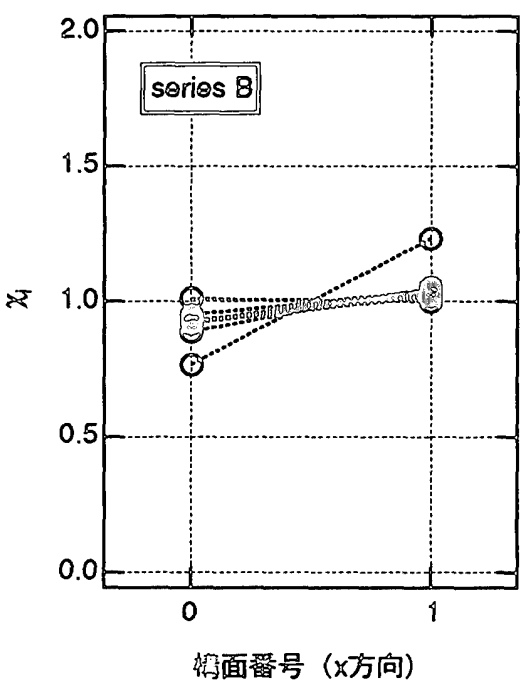

谁面㼭号 ( $($ 方向)

表 2 累栍塑性変形倍率の割増率

\begin{tabular}{|c|c|c|c|c|c|c|c|c|c|c|c|c|c|c|}
\hline model & $\mathrm{A} 01$ & $\mathrm{~A} 02$ & $\mathrm{~A} 03$ & $\mathrm{~A} 04$ & $\mathrm{~A} 05$ & $\mathrm{~B} 01$ & $\mathrm{~B} 02$ & $\mathrm{~B} 03$ & $\mathrm{~B} 04$ & $\mathrm{~B} 05$ & $\mathrm{~B} 06$ & $\mathrm{~B} 07$ \\
\hline$x_{0}$ & 0.67 & 0.74 & 0.83 & 0.93 & 1.01 & 1.01 & 0.95 & 0.95 & 0.93 & 0.92 & 0.89 & 0.77 \\
\hline$x_{1}$ & 1.02 & 1.03 & 1.08 & 1.03 & 1.01 & 1.00 & 1.04 & 1.03 & 1.03 & 1.02 & 1.05 & 1.23 \\
\hline
\end{tabular}


であり，式(10)(15)を式(14)に代入して，

$$
\begin{aligned}
W_{p i} & =q_{i}^{2} \cdot \frac{T^{2}}{4 \pi^{2} M \kappa_{i}} \cdot \eta_{i} \\
& =\frac{\alpha_{i}^{2} M^{2} g^{2}}{4} \cdot \frac{T^{2}}{4 \pi^{2} M \kappa_{i}} \eta_{i} \\
& =\frac{M g^{2} T^{2}}{4 \pi^{2}} \cdot \frac{1}{4 \kappa_{i}} \cdot \alpha_{i}^{2} \eta_{i}
\end{aligned}
$$

よって， $W_{p i}$ を $\frac{M g^{2} T^{2}}{4 \pi^{2}}$ で除した無次元化量 $A_{p i}$ を用いれば，構面 ごとの損傷分布は以下のように表せる。

$$
\begin{aligned}
\frac{A_{p i}}{A_{p}} & =\frac{\frac{1}{4 \kappa_{i}} \alpha_{i}^{2} \eta_{i}}{\sum_{j} \frac{1}{4 \kappa_{j}} \alpha_{j}^{2} \eta_{j}} \\
& =\frac{\frac{\alpha_{i}^{2}}{\kappa_{i}} \eta_{i}}{\sum_{j} \frac{\alpha_{j}^{2}}{\kappa_{j}} \eta_{j}}
\end{aligned}
$$

最適強度分布下での損傷分布は，式(17)に $\alpha_{i}=\bar{\alpha}_{i} \alpha$ を代入し, $\eta_{i}$ が $i$ によらず一定であることを考慮すれば,

$$
\begin{aligned}
& \frac{A_{p i}}{A_{p}}=\frac{s_{i}}{\sum_{j} s_{j}} \\
& s_{i}=\frac{\bar{\alpha}_{i}^{2}}{\kappa_{i}}
\end{aligned}
$$

と求めることができる。

また，一般の強度分布下においては，式(17)に

$\eta_{i}=\chi_{i} \eta_{n}, \alpha_{i}=p_{\hbar t} \bar{\alpha}_{i} \alpha$ を代入することで,

$$
\frac{A_{p i}}{A_{p}}=\frac{\frac{p_{t i}^{2} \bar{\alpha}_{i}^{2} \alpha^{2}}{\kappa_{i}} \chi_{i} \eta_{n}}{\sum_{j} \frac{p_{j}^{2} \bar{\alpha}_{j}^{2} \alpha^{2}}{\kappa_{j}} \chi_{j} \eta_{n}}
$$

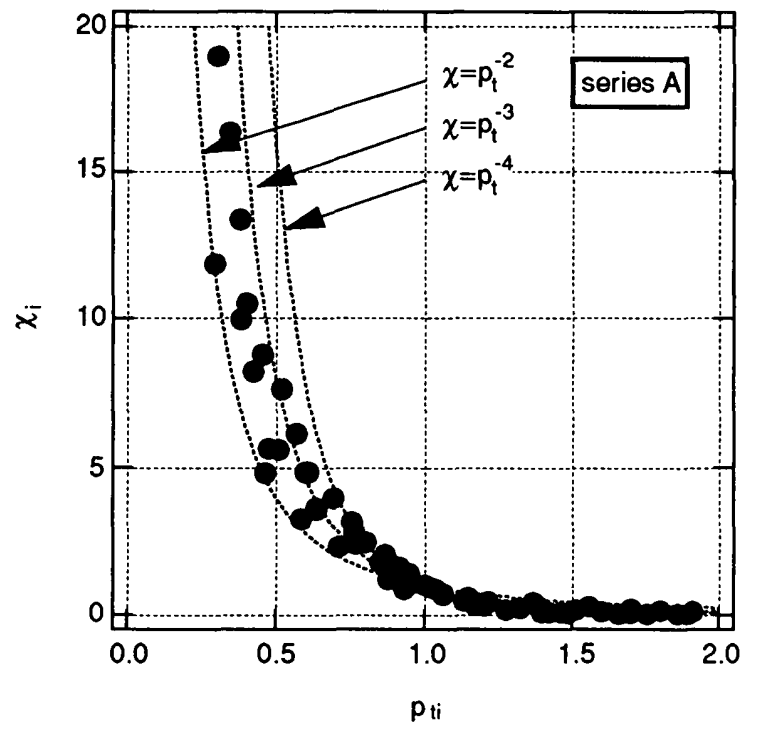

(a) 剛性分布をパラメータとした場合

$$
=\frac{\frac{\bar{\alpha}_{i}^{2}}{\kappa_{i}} p_{t i}^{2} \chi_{i}}{\sum_{j} \frac{\bar{\alpha}_{j}^{2}}{\kappa_{j}} p_{j}^{2} \chi_{j}}
$$

と求められる。ここで, 累積塑性変形倍率の割增率 $\chi_{i}$ と $p_{t i}$ との 間に式(12)の関保が認められるならば，式(20)は式(12)(19)を用 いて，以下のように表すことができる。

$$
\frac{A_{p i}}{A_{p}}=\frac{s_{i} p_{t i}^{-n^{\prime}}}{\sum_{j} s_{j} p_{t j}^{-n^{\prime}}} \quad\left(n^{\prime}=n-2\right)
$$

ここで, 応答解析の結果から $n^{\prime}=0 \sim 1$ であり，これは摸れ系に おける各構面の損傷分布が，据れの程度によらず最適強度分布下で の損傷分布から大きな変動がないことを示している。つまり，層間 の損傷集中に比べ，续れ要因による損傷集中は極めて小さいといえ よう。

\section{5 最適強度分布に基ついた強度低下率}

\section{1 強度低下率の定域}

4 節の結果から，㨝れ要因による損鹪集中は極めて小さいもので あり，各棈面の損傷配分は，挨れ要因の存在の有無によらずほほ一 定であることが判明した。これは, 最適強度分布を基準として考え た場合に据れによる損傷集中を等価な強度の低下率ととらえること が可能であることを示す。

まず，各構面の損傷配分が据れ要因の存在によらず一定であると 仮定する。これは式(21)から，式(12)において $n=2$ とすること を意味する。図 6 によれば $n=2$ とした場合の曲線 $\chi=p_{t}^{-2}$ は累積 塑性变形倍率の割増率の最小值を包絡しており，この仮定は耐震設 計上やや危険側となる。

ここで, 構造物への入力エネルギーは㨭れの度合いによらず一定

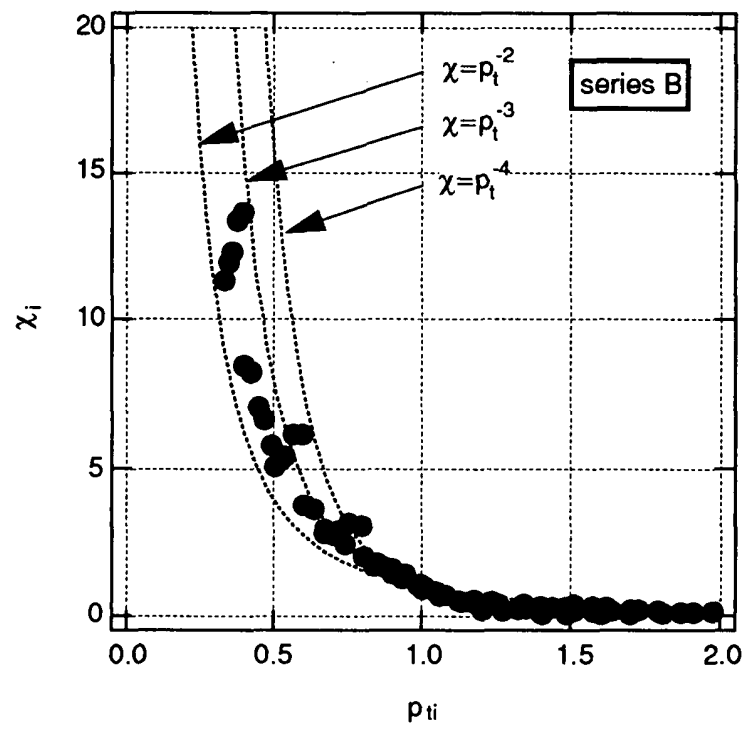

(b) 辺長此をパラメータとした場合

図 6 累積塑性変形倍率の割增率 $\chi$ 


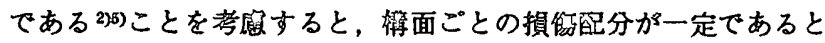
いう仮定に従えば，属全体の強度が等しい系に好いては，各構面の 累栍程みエネルギー $A_{p i}$ は強度分布によらず一定となる。

累皘歪みエネルギー $A_{p i}$ が一定である場合, 㩐面の降伏せん断 力係数 $\alpha_{i}$ と累䅪塑性変形倍率 $\eta_{i}$ の間には,

$$
A_{p i}=\frac{1}{4 \kappa_{i}} \alpha_{i}^{2} \eta_{i} \Leftrightarrow \alpha_{i}^{2} \eta_{i}=4 \kappa_{i} A_{p i} \text { (Const) }
$$

なる関係が成立するので，据れによって糸䅪塑性変形倍率が割增さ れる場合は，これを等価な強度低下率で表現することが可能であ る。

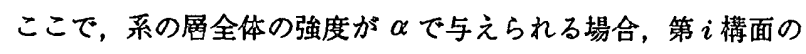
累皘塑性変形倍率が，据れを無視した 1 咓点系の累皘塑性变形倍率 $\eta_{n}$ と等しくなるのは, 各棈面の強度分布が最適強度分布に従う場

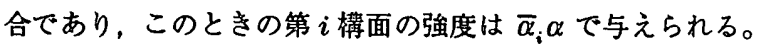

よって，据れ要因の存在により，第 $i$ 構面の累稜塑性変形倍率が $\eta_{n}$ から $\eta_{i}$ 八割增されたと考えれば, これと等価に第 $i$ 棈面の強 度は $\bar{\alpha}_{i} \alpha$ から $\alpha_{i}$ 入低減したものと考えることができる（図 7 参

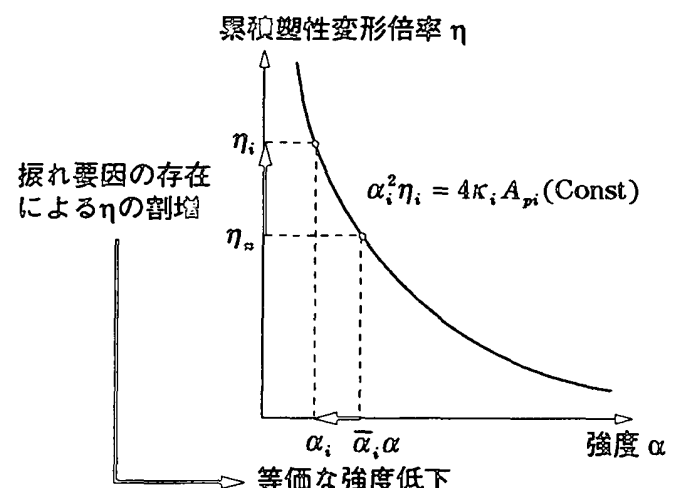

図 7 䍗積塑性変形倍率と等価な強度低下

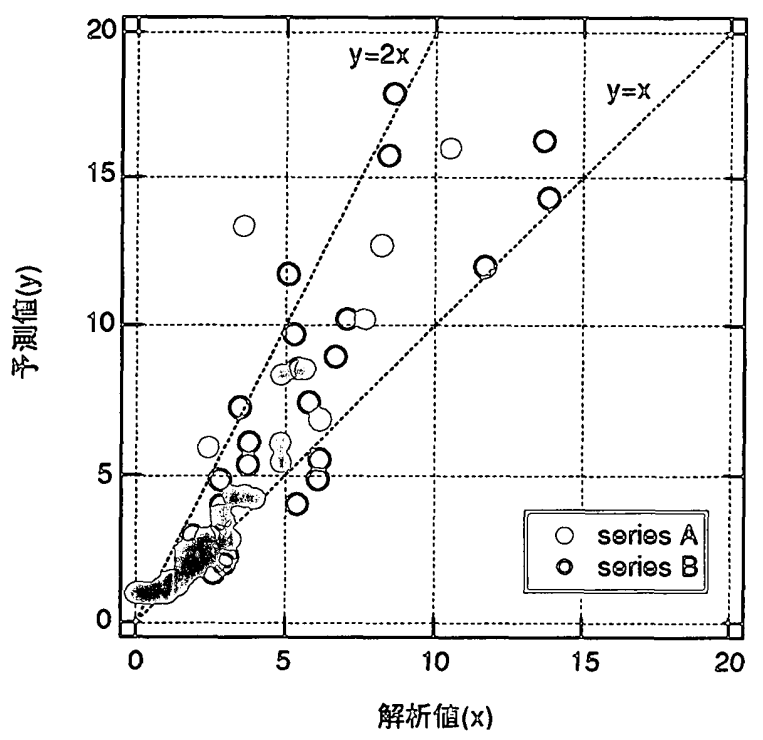

図 8 強度低下率に基づく $\chi$ の予測值と解析値との比皎
照)。以上より，昭唲塑性变形倍率の割増率 $\chi_{i}\left(=\eta_{i} / \eta_{0}\right)$ と等価 な強度低下率は，

$$
\frac{\alpha_{i}}{\bar{\alpha}_{i} \alpha}=p_{t i}
$$

と表すことができる。

しかし，式(23)如層全体の強度が等しい系での実際の強度と取 適強度分布下の強度との比を取っていることから明らかな通り, 橔 面によっては， $p_{t i}$ の值が 1 以上になってしまう。これは，据れ要 因の存在により，棈面によっては強度が逆に割り增されることがあ ることを意味し，現実に即した結果とはいえない。この現智は，前 述の損㢸配分一定という仮定が危険側であったことに起因するもの であるから、この評価にある程度のペナルティーを潩す必要があ る。そこで，この強度低下率が 1 を超えないよう全㩐面の強度低下 率を均等に縮小する。すなわち， $p_{t i}$ の最大值を $p_{t \max }$ として，第 $i$ 榑面の強度低下率を，

$$
p_{t i} / p_{t \max }
$$

と表すこととする。

この場合，式(24)で表される強度低下を受けた瀞面の累程塑性 変形倍率の 1 咓点系（あるいは最適強度分布に従う系）に対する割 增率 $\chi_{i}$ は,

$$
x=\left(\frac{p_{t i}}{p_{t \max }}\right)^{-2}
$$

と表せることから，これをこの強度修正法による $\chi$ の予測値と考 え，応答解析結果と比較したものが，図8である。予測值はやや安 全側の評価となっているが, 解析值の 2 倍以内にほほ収まってお ク，椪面ごとの提れによる強度低下を評価する現実的な手段とし て，本手法が有効であると考えられる。 5.2 他の強度補正法との比軦

次に，前述の強度低下率による損偤集中の予測崝度を，他の文献

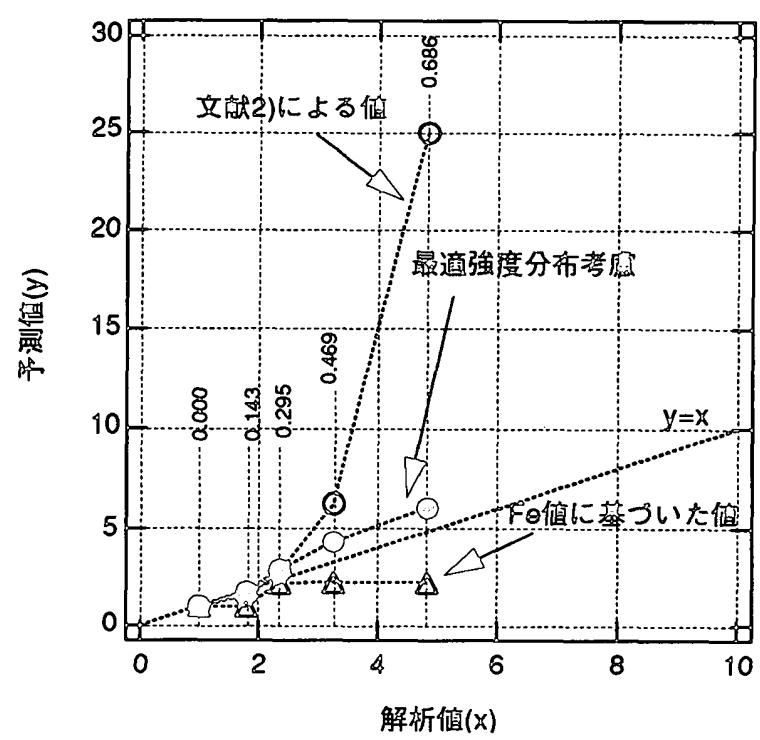

図 9 他の手法との予測綪度の比琝 
によるものと比較する。ここでは，もっぱら強度の不釣合に着目し て損賃集中を評価したものとして文献 2)を，また，弾性時の偏心 に着目したものとして，建築基準法で定められた $\mathrm{Fe}$ 值を比較対象 とする。

比較に用いるモデルは，現実的な構造物に即したものとして，正 方形床面を有する series Aのうち，強度分布と剛性分布が，

$$
k_{0} / K=q_{0} / Q=0.1,0.2,0.3,0.4,0.5
$$

のように比例する，全 5 モデルを採用する。

まず，文献 2)の手法によれば，損傷集中構面の累積塑性変形倍 率 $\eta_{i}$ は損傷集中構面の強度 $\alpha_{i}$ を用いて,

$$
\eta_{i}=\frac{A_{E}}{\alpha_{i}^{2}}
$$

で評価できる。この場合, 式(9), (26)より, 累積塑性変形倍率の 割增率 $\chi_{i}$ は,

$$
\chi_{i}\left(=\frac{\dot{\eta}_{i}}{\eta_{n}}\right)=\left(\frac{\alpha_{i}}{\alpha}\right)^{-2}
$$

と表せるので，式(27)を文献 2)による予測值とする。

また，建築基準法による Fe 值を用いた場合，摸れによる強度の 低下率 $p_{t}$ は，

$$
p_{t}=\frac{1}{F e}
$$

と考えられるので 2), 式(24)と同様にして, 累積塑性変形倍率の割 增率 $\chi_{i}$ は,

$$
\chi_{i}=\left(\frac{1}{F e}\right)^{-2}=F e^{2}
$$

で与えられる。そこで，これを Fe 值による予測式とする。

式(24)，(26)，(28)による予測値と解析値とを比較したものが図 9 である。なお，図中の数值は各モテルに対し，建築基準法で定め られた偏心率 $R e$ を示す。偏心の度合いの小さいモデルでは，予測 値は 3 者とも解析值と良い対応を見せているが, 偏心の度合いが大 きくなるにつれ，文献2)による予測は過度に安全側の評価を，逆 に Fe 值による予測は危険側の評価を与えるようになる。しかし， 倡心の大きなモデルの偏心率は，0.686に達しており，このモデル があまり現赛的なものではないのも事実であるから，この結果を従 来の指標を否定するものと安易に判断するのは避けるべきである。

最適强度分布を考慮した本手法では，偏心が大きいモデルにおい ても，予測值と解析值は良い对応を見せており，据れが予測される 斠造物の耐震設計に対しする本手法が有効性を改めて確認できたと いえよう。

\section{6 結論}

本研究では, 任意の剛性比, 強度比をもつ立体架構の強震時の損
傷を大局的にとらえるため，挨れ振動の影響を最も端的に受ける 1 層 $2 \times 2$ 構面 1 軸偏心構造物を対象とした応答解析を行った。

損傷分布を評価するに当たり，まず，各構面の損傷の度合い（累 積塑性変形倍率）を均一化するような最適強度分布を弾性モード解 析結果をもとに算出し，その有効性を確認した。

そして，この最適強度分布からのずれの度合いを指標として，損 傷分布を評価することを試みた。その結果, 実際の強度分布の最適 強度分布からのずれの度合い $p_{t i}$ により, 各構面の損傷分布は支配 的な影響を受けること，および，得られた解析結果から，摸れを無 視した 1 質点系の累積塑性変形倍率を基準とした場合の各構面の累 積塑性変形倍率の割増率が式(12)の形で評価できることをもとに， 摸れによる損侮分布（各構面の累積塑性変形歪みエネルギーの分 布）が摸れ要因の存在の有無によらずほほ一定であることを示し た。

このことは，摸れによる損傷の集中を等価な強度低下ととらえる ことが可能であることを示したものであり，この観点から，最適強 度分布を基準として，各構面ごとの挨れ要因の存在による強度低下 率を式(23)のような簡単な形で表すことができることを示した。 ここで定義された強度低下率は従来の層ごとの強度補正ではなく， 層内の構面ごとに強度を補正できるものであり，一般の多構面をも つ構造物に対しても適用が可能であると予測できる。このことは， 挨れを伴う立体架構の絵合的な耐震設計法の確立に有効な知見を与 えるものであると考える。

\section{参考文献}

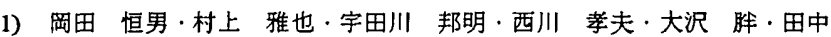
尚：1968 年十勝蚛地震による八戸市立図書館の被害に関する考察，日 本建築学会論文報告集, 1970 年 1 月, pp.47-56

2) 秋山 宏・東 清仁：鋼構造多層骨組の挨れに対する $\mathrm{Fe}$ 値について， 日本建築学会論文報告集，第 339 号，1984 年 5 月，pp.57-64

3）尾崎 昌凡·曾田 五月也·安田 征一郎·波川 智明：1層偏心構造 物の保有水平耐力と塑性交形に関する研究，日本建案学会構造系論文報 告集，第 364 号，1986 年 6 月, pp.63-60

4) 大網浩一・村上 雅也：1層1軸偏心線形系に扔けるねじれ成分の特 性，日本建姃学会構造系論文報告集，第 471 号，1995 年 5 月，pp.51-60

5) 秋山 宏: 建築物の耐震極限設計 第 2 版, 東大出版会, 1987 年

6）佐武 直紀：不整形状を有する建物のねじれに対する保有水平耐力の適 正配分に関する研究，日本建築学会構造系論文報告集，第 445 号，1993 年 3 月, pp.45-54

7) 柴田 明德：最新 耐震構造解析，森北出版，1981 年

8）田治見 去：建築振動学, コロナ社, 1965 年

9）山崎 裕：偏った剛性分布をもつ構造物のねじれ応答，日本建築学会構 造系論文報告集，第 369 号，1986 年 11 月，pp.31-41

（1997年 7 月10日原稿受理，1997年10月23日採用決定） 